\title{
Pengembangan LKPD Tanah Airku Sub Tema Kota Palembang untuk Anak Kelompok B
}

\author{
Gustiana Yuantini ${ }^{1}$, Hasmalena ${ }^{2}$, Syafdaningsih ${ }^{3}$
}

Received: 1912 2019/ Accepted: 2312 2019/ Published online: 28122019

(c) 2019 Early Chilhood Islamic Education Study Program

\begin{abstract}
This research aims to develop valid and practical student worksheet. Subjects in this research were B2 and B3 groups in state kindergarten of Pembina 2 Palembang. The model developed in this development was Rowntree consisting of One to one evaluation and small group evaluation. It was aimed to see the practicality and it used the Tessmer evaluation stage which consisted of self evaluation, expert review. Data collection techniques used in this research were interview, walkthrough and observation methods. According to the results of the research, it showed that the validity of the material and design obtained an average value of 3.77 in very valid categories. Student worksheet practicality test in terms of observations with a mean value of $95 \%$ in very practical category. The small group evaluation stage obtained an average score of $92 \%$ in the very practical category. Questionnaire result was $97 \%$ in valid category. From the result, it can be concluded that student worksheet theme of my homeland and subtheme of Palembang city for group B children is valid and practical. It is also worth to use as learning student worksheet with Theme of my homeland.
\end{abstract}

Keywords: student worksheet development, my homeland, B group, Palembang city.

Abstrak: Penelitian ini bertujuan untuk mengembangkan LKPD yang valid dan praktis. Subjek pada penelitian ini adalah kelompok B2 dan kelompok B3 di TK Negeri Pembina 2 Palembang. Model yang dikembangkan pada pengembangan ini yaitu Rowntree terdiri dari One to one evaluation dan small group evaluation bertujuan untuk melihat kepraktisan dan menggunakan tahap evaluasi Tessmer yang terdiri dari self evaluation, expert review. Teknik pengumpulan data yang digunakan pada penelitian ini adalah metode wawancara, walkthrough dan observasi. Berdasarkan hasil penelitian menunjukkan bahwa validitas materi dan desain diperoleh rerata nilai 3.77 kategori sangat valid. Uji kepraktisan LKPD ditinjau dari observasi dengan nilai rerata $95 \%$ kategori sangat praktis. Tahap small group evaluation diperoleh rerata nilai $92 \%$ kategori sangat praktis. Hasil angket $97 \%$ kategori valid. Hasil penelitian ini menyimpulkan bahwa LKPD tema tanah airku sub tema kota Palembang untuk anak kelompok B valid dan praktis serta layak digunakan sebagai LKPD pembelajaran Tema Tanah Airku.

Kata kunci : pengembangan LKPD, tanah airku, kelompok B, kota Palembang,

\footnotetext{
${ }^{1}$ Mahasiswi PIAUD Magister UIN Sunan Sunan Kalijaga

${ }^{2}$ Dosen PG. PAUD Universitas Sriwijaya

${ }^{3}$ Dosen PG. PAUD Universitas Sriwijaya
} 


\section{PENDAHULUAN}

Berdasarkan Peraturan Menteri Pendidikan dan Kebudayaan Republik Indonesia Nomor 137 Tahun 2014 tentang Standar Nasional Pendidikan Anak Usia Dini Bab VI Standar Isi Pasal 9 ayat 2 yaitu, tema dan sub tema sebagaimana yang dimaksud pada ayat (1) disusun sesuai dengan karakteristik, kebutuhan, tahap perkembangan anak, dan budaya lokal (Permendikbud, 2014b). Senada dengan peraturan menteri di atas terdapat pula peraturan menteri Nomor 146 Tahun 2014 tentang kurikulum 2013 terdapat kompetensi dasar yaitu nomor 3.7 mengenal lingkungan sosial (keluarga, teman, tempat tinggal, tempat ibadah, budaya dan transportasi) dan 4.7 menyajikan berbagai karya yang berhubungan dengan lingkungan sosial (keluarga, teman, tempat tinggal, tempat ibadah, budaya, transportasi) dalam bentuk gambar, bercerita, bernyanyi dan gerak tubuh (Permendikbud, 2014a, pp. 7-8). Berdasarkan pertimbangan itulah maka selaku pendidik anak usia dini kita harus mengenalkan tentang lingkungan sosial khususnya budaya yang terdekat di lingkungan anak seperti nama kota, ikon, makanan khas, tarian daerah, permainan tradisonal, lagu daerah, dan pakaian adat dilingkungan sekitar anak.

Menurut Koentjaraningrat (Rahmawati, 2012, p. 76) "buddhayah" merupakan kata dasar dari "budaya" berasal dari bahasa Sansekerta yang bearti "budi" atau "akal". Sehingga dapat dikatakan bahwa budaya menurut Koentjaraningrat ialah sebagai "daya budi" yang berupa cipta, karsa dan rasa. Keseluruhan sistem gagasan, tindakan yang berkaitan dengan hasil karya manusia dalam kehidupan bermasyarakat. Adapun menurut Ki Hajar Dewantara yang menyatakan bahwa kebudayaan ialah sesuatu yang dipengaruhi kuat oleh zaman dan alam yang menjadi bukti bahwa manusia pernah berjaya serta dapat mengatasi berbagai masalah maupun ritangan dalam kehidupan sehingga mencapai kedamaian dan ketentraman hidup. Pendapat lain ialah budaya merupakan suatu cara hidup yang diturunkan dari gerasi ke generasi yang berkembang dan dimilki bersama oleh sebuah kelompok manusia. Budaya menurut beberapa masyarakat dapat menjadi pedoman kehidupan dalam banyak hal misalnya, prilaku, agama, bahasa dan sebagainya.

Setelah peneliti melaksanakan observasi di 3 Taman Kanak-kanak kelompok B yang ada di kota Palembang diantaranya TK Al-Ikhlas, TK Pertiwi 1 dan TK Puri Abadi yang masing-masing observasi dilakukan pada tanggal 30 November 2017 dan 4 Desember 2017. Hasil wawancara dengan guru kelas pada saat itu untuk TK Al-Ikhlas yang berada di jalan K.H Wahid Hasyim Kec. Seberang Ulu 1 dan TK Pertiwi 1 yang berada di jalan Bungaran, secara umum dapat dikatakan bahwa pada saat pembelajaran tema tanah airku guru hanya mengandalkan LKPD atau yang biasa mereka sebut dengan majalah untuk anak yang mereka beli per paket pada tiap semester.

Pengembangan tema itu tersendiri khususnya untuk mengenalkan kota Palembang sebagai budaya lokal yang harus diketahui anak, guru kelas tidak memiliki media khusus untuk mengenalkan budaya lokal Palembang mereka hanya mencetak gambar monumen khas Palembang misalnya jembatan Ampera, Monpera, Masjid Agung dll, serta mengajak anak untuk tanya jawab seputar pusat kota Palembang. Kemudian kendala yang guru hadapi adalah untuk penyediaan media itu sendiri misalnya mereka harus mencetak gambar terlebih dahulu sebelum memberikan materi kepada peserta didik, kemudian ukuran yang dihasilkan tidak begitu besar bahkan tidak terlihat jelas oleh seluruh anak karena menggunakan kertas A4. Untuk LKPD yang digunakan oleh TK Al- Ikhlas ialah buku dari penerbit Intan Pariwara yang mengacu pada kurikulum 2013 yang setiap temanya tersebar dalam 7 (tujuh) buku yang berbeda judul. Sedangkan buku yang digunakan oleh TK Pertiwi 1 dengan penerbit yang sama pada TK sebelumnya namun pada buku ini mengacu pada Pemediknas No. 58 Tahun 2009, buku ini dicetak pertema 
seperti pada buku umumnya. Terkhir TK Puri Abadi menggunakan buku buah karya Ester Lasepta oleh penerbit Zikrul Hakim. Buku ini telah mengacu pada kurikulum 2013, dan dicetak pertema. Berdasarkan beberapa kendala yang telah peneliti temukan seperti yang dibahas sebelumnya ialah kurangnya bahan ajar dalam hal ini ialah LKPD yang berkaitan dengan kebudayaan lokal Palembang, karena pada umumnya LKPD tema tanah airku dari masing-masing LKPD yang digunakan oleh sekolah mencakup budaya yang ada di Indonesia namun isi dari materi tersebut terkadang tidak berkaitan dengan lingkungan budaya sekitar anak.

Kemudian dari hasil wawancara dengan guru kelas, guru sangat setuju jika ada bahan ajar atau LKPD tentang budaya lokal Kota Palembang. Guru merasa sangat terbantu dengan adanya LKPD tentang sub tema kota Palembang, setidaknya guru tidak perlu lagi mencetak media ataupun lembar kegiatan peserta didik. Sehingga dapat menghemat waktu dan lebih praktis dalam penggunaannya. Bagi anak dengan adaanya LKPD ini dapat memberikan pengetahuan tentang budaya lokal kota Palembang yang merupakan kota tempat anak dibesarkan. Untuk itulah perlu dikembangkan LKPD sub tema kota Palembang. Berdasarkan identifikasi masalah di atas maka peneliti bermaksud mengembangan Lembar Kegiatan Peserta Didik (LKPD) Tanah Airku Sub Tema Kota Palembang untuk Kelompok B Di TK Negeri Pembina 2 Palembang.

\section{METODE}

Penelitian ini menggunakan metode penelitian pengembangan. Selanjutnya model yang akan digunakan pada penelitian ini merujuk pada model Rowntree, terkait dengan proses dalam model pengembangan ini lebih spesifik, singkat dan jelas serta bertujuan mengembangkan produk khususnya lembar kegiatan peserta didik (Prawiradilaga \& Salma, 2016, p. 45). Tahap dari model ini adalah perencanaan, pengembangan, dan penilaian atau evaluasi. Model evaluasi yang digunakan ialah evaluasi formatif Tessmer yang meliputi dari beberapa tahap diantaranya self evaluation (evaluasi mandiri), expert review (ulasan para ahli), one-to-one evaluation (evaluasi satu persatu), dan yang terakhir small group evaluation (evaluasi kelompok kecil) (Tessmer, 1993, p. 16). Pada bulan November-Desember 2017 penelitian ini telah dilakukan pada tahap perencanaan. Subjek pada penelitian ini adalah kelompok B2 dan kelompok B3 di TK Negeri Pembina 2 Palembang dan tahap evaluasi dilakukan pada bulan Maret 2018.

\section{Perencanaan}

Terdapat tiga kegiatan dalam tahap analsis berikut ini:

a) Peserta didik dianalisis berdasarkan kompetensi

pada tahap ini peneliti menganalisis kompetensi yang sesuai dengan usia anak pada peraturan pemerintah no. 146 tahun 2014 tentang kurikulum 2013 pada anak usia dini, diantaranya adalah sebagai berikut: 1.2 menghargai diri sendiri, orang lain, dan lingkungan sekitar sebagai rasa syukur kepada Tuhan. 3.7 Mengenal lingkungan sosial (keluarga, teman, tempat tinggal, tempat ibadah, budaya dan transportasi). 4.7 menyajikan berbagai karya yang berhubungan dengan lingkungan sosial (keluarga, teman, tempat tinggal, tempat ibadah, budaya, transportasi) dalam bentuk gambar, bercerita, bernyanyi dan gerak tubuh, 3.5 mengetahui cara memecahkan masalah sehari-hari dan berprilaku kreatif. 3.6 mengenal benda-benda disekitrnya (nama, warna, bentuk, ukuran, pola, sifat, suara, teksur, fungsi dan ciri-ciri lainnya). 4.5 menyelesaikan masalah secara kreatif. 4.3 menggunakan anggota tubuh untuk 
mengembangkan motorik kasar dan halus. 4.11 menunjukkan kemampuan berbahasa ekspresif (menungkapkan bahasa secara verbal dan non verbal). 4.12 menujnjukkan kemampuan keaksaraan awal dalam berbagai bentuk karya. 4.15 menunjukkan karya dan aktivitas seni dengan menggunakan berbagai media. 4.6 Menyampaikan tentang apa dan bagaimana benda-benda yang ada disekitar yang dikenalnya (nama,warna, bentuk, pola, suara, tekstur, ukuran, fungsi dan ciri lainnya) melalui berbagai hasil karya.

b) Kapasitas karakteristik belajar peserta didik dianalisis yang meliputi keterampilan, penngetahuan serta sikap dan aspek lain yang terkait;

c) Materi dianalisis sesuai dengan tuntutan kompetensi. Pada tahap ini peneliti melakukan analisis KI, KD dan indikator untuk anak usia 5-6 tahun yang sesuai dengan tema tanah airku yang telah di jelaskan pada bab sebelumnya. Selanjutya referensi pendukung yang digunakan dalam mengembangkan LKPD dikumpulkan. Rujukan yang digunakan dapat berupa jurnal, situs internet terpercaya, soft file maupun buku.

\section{Pengembangan}

Tahap selanjutnya setelah tahap perencanaan ialah tahap pengembangan topik, seperti yang telah dijelaskaan pada bab sebelumnya yaitu tentang kebudayaan lokal kota Palembang dan telah disesuaikan dengan kompetensi dasar serta tujuan pembelajaran.

Setelah menyusun materi selesai selanjutnya ialah membuat prototipe. Setelah materi disusun selanjutnya diaplikasikan pada lembar kegiatan peserta didik yang telah diilustrasikan ke dalam gambar.

\section{Evaluation/ evaluasi}

Kevalidan dan kepraktisan produk dapat dianalisis melalui tahap evaluasi pada LKPD yang kita implementasikan. Evaluasi formatif adalah proses yang dimasukkan untuk mengumpulkan data tentang efektifitas dan efisiensi bahan-bahan pembelajaran (termasuk kedalamnya media) untuk mencapai tujuan yang telah ditetapkan. Evaluasi formatif dilakukan dengan tujuan adalah untuk melakukan perbaikan-perbaikan atau menilai tentang kemajuan produk, bahan, material dan rancangan atau desain (Setyosari, 2016, p. 288). Agar dapat menentukan kelayakan produk, bahan, material dan rancangan desain dapat dilakukan menggunakan tes formatif dari Tessmer yang akan dipaparkan berdasarkan langkah-langkah di bawah ini:

\section{Self Evaluation}

Pada langkah ini LKPD telah dihasilkan kemudian peneliti melakukan koreksi sendiri terhadap LKPD Tema Tanah Airku Sub Tema Kota Palembang yang telah dikembangkan. Setelah dilakukan koreksi maka dilanjutkan pada tahap evaluasi berikutnya yaitu expert review.

\section{Expert Review}

Pada tahap ini LKPD dievaluasi oleh para ahli. Kriteria yang diperlukan untuk memilih validator pada penelitian ini ialah mereka yang dianggap ahli dan sudah berpengalaman untuk melakukan penilaian terkait dengan produk yang akan dikembangkan. Ada dua validator yang dilibatkan pada tahap ini yaitu ahli materi yang bertujuan untuk menilai kelaayakan materi dan menilai kesesuaian materi serta soal 
berdasarkan kompetensi dan tujuan yang akan dicapai. Validator selanjutnya ialah ahli media yang bertugas untuk menilai desain serta bahasaa yang akan digunakan.

Prosedur yang digunakan pada tahap ini dengan pemberian angket yang telah disediakan. Selanjutnya saran-saran yang telah diberikan validator dianalisa kemudian dijadikan sebagai bahan revisi. Jika terdapat hal-hal yang harus diperbaiki maka peneliti harus merevisi LKPD tersebut. Jika telah dinyatakan valid maka LKPD yang telah melewati tahap review ahli selanjutnya akan dilakukan one-to-one evaluations.

\section{One-To-One Evaluation}

Melalui evaluasi one-to-one atau evaluasi uji satu-satu ini peneliti melibatkan tiga peserta didik kelompok B TK Negeri Pembina 2 Palembang yang dapat merepresentasikan kemampuan peserta didik di kelas yaitu dengan kategori low, middle dan high (Tessmer, 1993, p. 22). Kemudian mereka diminta untuk mengerjakan tugas pada LKPD tersebut. Setelah LKPD telah memiliki kepraktisannya pada tahap one-toone evaluations tersebut kemudian LKPD yang telah direvisi melalui uji ahli dinamakan prototipe 2 dilanjutkan ke tahap small group evaluations.

\section{Small Group Evaluation}

Evaluasi kelompok kecil ialah evaluasi yang dilakukan dengan cara mengujicobakan prototipe 2 yang telah dikembangkan pada kelompok siswa yang terdiri dari sembilan pesertadidik, yang dibagi kedalam tiga kemampuan, yaitu dengan kemampuan tinggi, kemampuan sedang dan kemampuan rendah selain itu dengan karakteristik yang berbeda seperti dari latar belakang keluarganya suku dan lain-lain. Peserta didik kemudian diminta kembali untuk mengerjakan tugas pada LKPD tersebut. Kemudian setelah dilakukan perbaikan dan prototipe 2 telah memiliki kepraktisan maka produk telah selesai.

\section{Teknik Pengumpulan Data}

Wawancara guru merupakan teknik yang dilakukan untuk pengumpulan data penelitian yang digunakan sebagai analisis data awal. Kemudian teknik walkthrought adalah hasil evaluasi produk yang dilakukan oleh beberapa ahli untuk memvalidasi data sebagai acuan untuk memperbaiki produk awal. Lembar validasi ahli digunakan sebagai alat untuk melakukan evaluasi terhadap produk yang dikembangkan yang berupa skala likert.

Tabel 1. Bobot Penilaian Walkthrought

\begin{tabular}{cc}
\hline Pernyataan & Skor \\
\hline Sangat Setuju (SS) & 4 \\
Setuju (S) & 3 \\
Tidak Setuju (TS) & 2 \\
Sangat Tidak Setuju (STS) & 1
\end{tabular}

(Sugiyono, 2013, p. 135) 
Rumus mencari rerata skor:

Persentase $=\frac{\text { Jumlah } \text { skor }}{\text { jumlah responden } \times \text { skor tertinggi }} \times 100$

Kategori dari nilai rata-rata:

Tabel 2. Kategori Nilai Kevalidan

\begin{tabular}{cc}
\hline Rata-Rata & Kategori \\
\hline $3,25-4,00$ & Sangat Valid \\
$2,50-3,24$ & Valid \\
$1,75-2,49$ & Tidak Valid \\
$1,00-1,74$ & Sangat Tidak Valid \\
\hline
\end{tabular}

Teknik pengumpulan data selanjutnya dalam penelitian ini adalah observasi. Observasi dilakukan pada saat kegiatan berlangsung yang bertujuan untuk melihat kepraktisan LKPD yang akan dikembangkan. Observasi dilaksanakan sebanyak 4 hari yaitu 2 hari tahap one-to-one dan 2 hari pada tahap small group. Observasi tersebut diukur melalui indikator pembelajaran yang telah ditentukan pada soal LKPD yang telah dibuat. Kemudian perolehan skor yang didapat diubah menjadi nilai. Seperti yang dikatakan sebelumnya ,data yang diperoleh berupa skor yang diubah jadi nilai mengacu pada penggunaan rumus Sunarti \& Rahmawati. Rumus seperti dibawah ini:

$$
\text { Nilai }=\frac{\text { Skor Peroleh }}{\text { Skor Total }} \times 100 \%
$$

(Sunarti \& Rahmawati, 2014:191)

Setelah mendapatkan nilai, kemudian menentukan kriteria sesuai dengan nilai yang didapat.

Tabel 3. Kategori Nilai Hasil Observasi

\begin{tabular}{cc}
\hline Skor $(\%)$ & Kategori \\
\hline $80-100$ & Baik Sekali \\
$70-79$ & Baik \\
$60-69$ & Cukup \\
$<60$ & Kurang \\
\hline
\end{tabular}

Dibawah ini merupakan tabel kriteria berdasarkan nilai hasil observasi yang dikonversikan.

Tabel 4. Kriteria Nilai Observasi Kepraktisan LKPD

\begin{tabular}{cc}
\hline Persentase & Kriteria interpretasi Skor \\
\hline $86 \%-100 \%$ & Sangat praktis \\
$76 \%-85 \%$ & Praktis \\
$60 \%-75 \%$ & Cukup praktis \\
$>59 \%$ & Tidak praktis \\
\hline
\end{tabular}


Untuk mengetahui kepraktisan terhadap penggunaan LKPD yang akan dikembangkan maka perlu dilakukan pemberian angket kepada guru. Tabel 5 di bawah ini merupakan bobot penilaian angket.

Tabel 5. Bobot Penilaian Angket

\begin{tabular}{cc}
\hline Pernyataan & Skor \\
\hline Sangat Setuju (SS) & 4 \\
Setuju (S) & 3 \\
Tidak Setuju (TS) & 2 \\
Sangat Tidak Setuju & 1 \\
(STS) & \\
\hline
\end{tabular}

(Sugiyono, 2013, p. 135)

Skala Likert dapat digunakan untuk memperoleh data melalui angket tentang tanggapan guru terhadap LKPD. Data yang telah terkumpul dapat dijadikan dalam bentuk persentase. Presentase dapat dicari dengan rumus:

$$
\text { Nilai Persentase }=\frac{\text { Skor yang didapat }}{\text { Skor Maksimum }} \times 100
$$

Tabel 6. Kriteria Interpretasi Skor Angket

\begin{tabular}{cc}
\hline Persentase & Kriteria interpretasi Skor \\
\hline $81 \%-100 \%$ & Sangat praktis \\
$61 \%-80 \%$ & Praktis \\
$41 \%-60 \%$ & Cukup praktis \\
$>60 \%$ & Tidak praktis \\
\hline
\end{tabular}

Berdasarkan tabel 6 LKPD dapat dikatakan praktis karena kriteria interpretasi skor angket mencapai $\geq 60 \%$

\section{HASIL PENELITIAN DAN ANALISIS}

Hasil penelitian yang berjudul pengembangan lembar kegiatan peserta didik tema tanah airku sub tema kota Palembang, dengan menggunakan model Rowntree melalui tiga tahap yaitu perencanaan, pengembangan dan tahap evaluasi. Tahap evaluasi yang digunakan adalah tahap evaluasi Tessmer yang terdiri dari self review, expert review, one to one evaluation dan small group evaluation. Berikut ini adalah uraian tahapan dalam pengembangan LKPD tanah airku sub tema kota Palembang. Untuk menentukan kelayakan produk, bahan, material dan rancangan desain dapat dilakukan menggunakan tes formatif dari Tessmer yang dipaparkan seperti di bawah ini :

\section{Self Evaluation}

Pada saat tahap evaluasi diri ini LKPD yang telah dihasilkan kemudian peneliti melakukan koreksi sendiri terhadap LKPD Tema Tanah Airku Sub Tema Kota Palembang yang telah 
dikembangkan. Setelah dilakukan koreksi maka dilanjutkan pada tahap evaluasi berikutnya yaitu expert review.

\section{Expert Review}

Pada tahap ini LKPD dievaluasi oleh para ahli. Kriteria validator yang dapat dipilih dalam mengevaluasi produk yang akan dikembangkan ialah ahli tersebut berkompeten dan berpengalaman dalam melakukan penilaian terkait dengan produk yang akan dikembangkan. Ada dua validator yang dilibatkan pada tahap ini yaitu ahli materi yang bertujuan untuk menilai kecocokan materi atau kesesuaian materi dan soal berdasarkan kompetensi dan tujuan pembelajaran yang akan dicapai. Selain itu, tampilan atau desain akan dinilai oleh ahli media.

Prosedur yang digunakan pada tahap ini dengan pemberian angket yang telah disediakan. Selanjutnya saran-saran yang telah diberikan validator dianalisa kemudian dijadikan sebagai bahan revisi. Jika terdapat hal-hal yang harus diperbaiki maka peneliti harus merevisi LKPD tersebut. Jika telah dinyatakan valid maka LKPD yang telah melewati tahap review ahli selanjutnya akan dilakukan one-to-one evaluations.

Tabel 1. Rekapitulasi Hasil Penilaian Validator

\begin{tabular}{ccc}
\hline No & Validasi & Rekapitulasi Nilai \\
\hline 1 & Content/materi & 3,76 \\
2 & Desain & 3,78 \\
\hline & Rata-Rata & 3,77 \\
& Kategori & Sangat Valid \\
\hline
\end{tabular}

Uji validitas dilakukan untuk menguji tingkat kevalidan LKPD, dengan melibatkan 2 ahli yaitu ahli desain dan materi. Rata-rata dari jumlah skor validasi ahli sebesar 3,77 dengan kategori sangat valid. Kedua validator mengizinkan uji coba produk setelah dilakukan revisi sesuai dengan saran-saran yang telah dilakukan.

\section{One-To-One Evaluation}

Pada tahap evaluasi one-to-one atau evaluasi uji satu-satu ini peneliti melibatkan tiga peserta didik kelompok B TK Negeri Pembina 2 Palembang yang mewakili peserta didik dengan kemampuan rendah, sedang dan tinggi (Tessmer, 1993, p. 22). Kemudian mereka diminta untuk mengerjakan tugas pada LKPD tersebut. Pemilihan subjek penelitian ditinjau dari tingkat kemampuan.

Tabel 2. Analisis Data Observasi Anak Terhadap Kepraktisan LKPD

\begin{tabular}{|c|c|c|c|c|}
\hline No & Nama & Skor & $\begin{array}{c}\text { Nilai } \\
\text { Persentase }\end{array}$ & Kategori \\
\hline 1. & MR & 28 & $100 \%$ & $\begin{array}{l}\text { Sangat } \\
\text { praktis }\end{array}$ \\
\hline 2. & NB & 27 & $96 \%$ & $\begin{array}{l}\text { Sangat } \\
\text { praktis }\end{array}$ \\
\hline 3. & MH & 25 & $89 \%$ & $\begin{array}{l}\text { Sangat } \\
\text { praktis }\end{array}$ \\
\hline & mlah & 80 & $285 \%$ & \\
\hline \multicolumn{3}{|c|}{ Rata-rata $(\%)$} & $95 \%$ & $\begin{array}{l}\text { Sangat } \\
\text { Praktis }\end{array}$ \\
\hline
\end{tabular}


Rata-rata skor dari tahap evaluasi one-to-one yaitu 95\% dengan kategori sangat praktis. Sedangkan tahap small group dengan melibatkan 9 peserta didik pada kelompok B3 dengan rerata nilai sebesar $92 \%$ dengan kategori sangat praktis.

Setelah LKPD telah memiliki kepraktisannya pada tahap one-to-one evaluations tersebut kemudian LKPD yang telah direvisi melalui uji ahli dinamakan prototipe 2 dilanjutkan ke tahap small group evaluations.

\section{Small Group Evaluation}

Tahap ini merupakan tahap evaluasi yang dilakukan dengan cara mengujicobakan prototipe 2 yang telah dikembangkan pada kelompok siswa yang terdiri dari sembilan pesertadidik, yang dibagi kedalam tiga kemampuan, yaitu dengan kemampuan tinggi, kemampuan sedang dan kemampuan rendah selain itu dengan karakteristik yang berbeda seperti dari latar belakang keluarganya suku dan lain-lain. Peserta didik kemudian diminta kembali untuk mengerjakan tugas pada LKPD tersebut. Kemudian setelah dilakukan perbaikan dan prototipe 2 telah memiliki kepraktisan maka produk telah selesai.

Pada kegiatan menempelkan potongan gambar Monpera dan masjid Agung anak merasa kebingungan dikarenakan tidak terdapat contoh gambar yang utuh sehingga setelah direvisi peneliti menambahkan gambar yang utuh pada kedua lembar kerja peserta didik tersebut. Untuk gambar lebih jelas dapat dilihat pada lampiran. Hasil observasi anak terhadap kepraktisan LKPD yang dikembangkan dapat dilihat pada tabel 3 sebagai berikut:

Tabel 3. Analisis Data Observasi Anak pada Tahap Small Group Evaluation

\begin{tabular}{|c|c|c|c|c|}
\hline No & Nama & Skor & $\begin{array}{c}\text { Nilai } \\
\text { Persentase }\end{array}$ & Kategori \\
\hline 1. & $\overline{\mathrm{AJ}}$ & 27 & $96 \%$ & $\begin{array}{l}\text { Sangat } \\
\text { praktis }\end{array}$ \\
\hline 2. & $\mathrm{AK}$ & 27 & $96 \%$ & $\begin{array}{l}\text { Sangat } \\
\text { praktis }\end{array}$ \\
\hline 3. & $\mathrm{ZY}$ & 27 & $96 \%$ & $\begin{array}{l}\text { Sangat } \\
\text { praktis }\end{array}$ \\
\hline 4. & FD & 27 & $96 \%$ & $\begin{array}{l}\text { Sangat } \\
\text { Praktis }\end{array}$ \\
\hline 5. & WW & 25 & $89 \%$ & $\begin{array}{l}\text { Sangat } \\
\text { praktis }\end{array}$ \\
\hline 6. & $\mathrm{RR}$ & 25 & $89 \%$ & $\begin{array}{l}\text { Sangat } \\
\text { praktis }\end{array}$ \\
\hline 7. & $\mathrm{LN}$ & 25 & $89 \%$ & $\begin{array}{l}\text { Sangat } \\
\text { praktis }\end{array}$ \\
\hline 8 & SL & 27 & $96 \%$ & $\begin{array}{l}\text { Sangat } \\
\text { Praktis }\end{array}$ \\
\hline 9. & $\mathrm{BM}$ & 24 & $85 \%$ & $\begin{array}{l}\text { Sangat } \\
\text { Praktis }\end{array}$ \\
\hline & Jumlah & 234 & $832 \%$ & \\
\hline \multicolumn{3}{|c|}{ Rata-rata $(\%)$} & $92 \%$ & $\begin{array}{l}\text { Sangat } \\
\text { Praktis }\end{array}$ \\
\hline
\end{tabular}

\section{Hasil Angket Kepraktisan LKPD}

Untuk mengetahui tingkat kepraktisan LKPD yang telah dikembangkan oleh peneliti maka diperlukan angket yang diberikan kepada tiga guru di TK Negeri Pembina 2 Palembang. Responden pada hal ini adalah guru yang mengajar pada kelompok B2. Praktikalitas adalah tingkat keterpakaian dan keterlaksanaan prototipe perangkat pembelajaran oleh guru dan siswa (Centaury, 2015, p. 88). Berdasrkan pendapat di atas peneliti meninjau tingkat kepraktisan dari 
segi penggunaan LKPD pada anak dan juga guru. Berikut ini adalah tabel penyajian data hasil angket kepraktisan LKPD yang dikembangkan oleh peneliti.

Tabel 4. Angket Guru Terhadap Kepraktisan LKPD Tema Tanah Airku Sub Tema Kota Palembang

\begin{tabular}{ccccc}
\hline No & Nama & Skor & $\begin{array}{c}\text { Nilai } \\
\text { Persentase }\end{array}$ & Kategori \\
\hline 1. & SZ & 31 & $96 \%$ & $\begin{array}{l}\text { Sangat } \\
\text { praktis }\end{array}$ \\
2. & YM & 31 & $96 \%$ & $\begin{array}{l}\text { Sangat } \\
\text { praktis }\end{array}$ \\
3. & NR & 32 & $100 \%$ & $\begin{array}{l}\text { Sangat } \\
\text { praktis }\end{array}$ \\
\hline \multicolumn{2}{l}{ Jumlah } & 94 & $292 \%$ & $\begin{array}{l}\text { Sangat } \\
\text { Praktis }\end{array}$ \\
\hline
\end{tabular}

Melalui tabel 4 di atas nilai angket kepraktisan terhadap LKPD yang telah didapatkan jumlah nilai rata-rata 97\% dengan kategori sangat praktis. Sehingga dapat dikatakan bahwa LKPD Tema Tanah Airku Sub Tema Kota Palembang telah memenuhi kriteria kepraktisan.

\section{PEMBAHASAN}

Penelitian yang dilakukan ini merupakan penelitian pengembangan yang bertujuan untuk mengembangkan LKPD Tema Tanah Airku Sub Tema Kota Palembang Untuk Anak Kelompok B. Model Rowntree digunakan sebagai model pengembangan dalam penelitian ini dengan menggunakan evaluasi Tesmer. Pembuktian dalam penelitian secara berurutan akan dipaparkan berikut ini.

Tahap validasi media yang terdiri dari 4 indikator diantaranya 1) kejelasan tulisan pada LKPD, tulisan tidak buram, tidak terjadi kesalahan pada penulisan, tulisan LKPD menarik untuk dibaca dan jenis huruf yang digunakan dapat terbaca, dengan mendapatkan total skor sebesar 22, 2) petunjuk penggunaan yang terdiri dari bahasa yang digunakan efektif dan efisien serta kejelasan informasi yang diberikan, dengan total skor 8,3) kejelasan gambar pada LKPD yaitu gambar tidak buram, posisi gambar strategis, terdapat penjelasan, gambar mudah dipahami dan mendapatkan total skor 15,4$)$ tampilan LKPD yang terdiri dari gambar sesuai dengan tema dan sub tema, menarik untuk dilihat, gambar disusun dengan teratur dan terdapat judul beserta keterangan lainnya, total skor yang didapatkan 16. Evaluasi desain dengan kategori sangat valid diperoleh rata-rata skor senilai 3.78 . Kemudian layak untuk diuji coba sesuai saran. Saran yang didapatkan oleh peneliti berupa ejaan atau penulisan diperbaiki, judul pindah ke bagian tengah atas lembar kerja, ukuran judul diperbesar dan buat langkah kerja peserta didik. Setelah saran dari validator diperbaiki maka layak untuk diuji coba.

Hasil validasi materi/content sebesar 3,76 dengan kategori sangat valid, kemudian untuk validasi desain sebesar 3,78 dengan kategori sangat valid. Dengan demikian, LKPD peneliti yang telah dikembangkan layak untuk dilanjutkan pada tahap uji coba berikutnya. Pada tahap prototipe 1 terdapat beberapa saran dari validator sehingga produk harus direvisi seperti yang telah dijelaskan pada tahap sebelumnya. Selanjutnya, LKPD dapat diuji coba pada tahap one to one setelah sebelumnya telah divalidasi kemudian direvisi. Berdasarkan hasil validasi dari tahap expert review yang diperoleh pada LKPD tema tanah airku sub tema Kota Palembang yaitu 3,7 dengan kategori sangat valid. Validitas isi yang dapat dikatakan valid apabila produk yang dikembangkan menggunakan teori yang memadai (Haviz, 2013, p. 33). Dikatakan validitas konstruk ialah adanya hubungan secara konsisten antara semua komponen produk pembelajaran antara satu dan yang lainnya. Senada dengan pendapat ahli di atas menurut Asikin dalam 
Fatmawati dikatakan valid apabila ada keterkaitan yang konsisten dari setiap komponen perangkat pembelajaran yang dikembangkan (Fatmawati, 2016, p. 95).

Prototipe 1 yang telah dievaluasi oleh validator pada tahap uji satu-satu (one to one evaluation) bertujuan untuk melihat kepraktisan dari produk yang dikembangkan ditahap prototipe 1 . Pada tahap ini melibatkan tiga orang anak, mereka secara bersamaan menggunakan LKPD tersebut. Tahap ini guru mengajarkan anak tentang kota Palembang yang merujuk dari tema tanah airku. Setelah guru menjelaskan materi tersebut anak mengerjakan LKPD yang telah disediakan. Pada saat pembelajaran peneliti mengamati anak, agar dapat melihat nilai kepraktisan LKPD yang dikembangkan terhadap prototipe 1. Adapun tiga indikator pengamatan yaitu 1) daya tarik, yang terdiri dari deskriptor antusias dalam mengerjakan LKPD, memperhatikan LKPD secara seksama, 2) kemudahan penggunaan, yang terdiri dari tiga deskriptor yaitu, memahami instruksi LKPD, memahami materi, menjawab soal secara mandiri, 3) minat atau motivasi terdiri dari dua deskriptor diantaranya berdiskusi atau bertanya dengan teman sekelompok mengenai materi dalam LKPD dan menunjukan rasa ingin tahu. Rata-rata yang diperoleh sebesar 95\% kategori sangat praktis. Hasil dari prototipe 1 kemudian direvisi lagi menjadi prototipe 2.

Kepraktisan terhadap penggunaan LKPD tema tanah airku sub tema Kota Palembang diujicobakan prototipe 2 pada anak yang disebut dengan small group evaluation. Pada tahap ini peneliti menggunakan sembilan anak kelompok B3 di TK Negeri Pembina 2 Palembang. Tahap ini peneliti kembali menjadi observer sekaligus melakukan dokumentasi melalui video dan foto. Guru memberikan materi tentang kota Palembang menggunakan media gambar atau print out yang telah disediakan oleh peneliti yang kemudian ditempelkan di media karton dan diletakkan di papan tulis kelas. Setelah guru menyampaikan materi tentang kota Palembang kemudian anakanak dipandu untuk mengerjakan LKPD yang telah disediakan oleh peneliti. Indikator yang digunakan untuk melihat tingkat kepraktisan pada tahap ini sama dengan indikator pada tahap sebelumnya yaitu tahap one to one evaluation. Nilai observasi pada tahap small group evaluation pada LKPD dengan rata-rata sebesar 92\% sehingga dapat dikatakan bahwa penggunaan LKPD tema Tanah Airku sub tema Kota Palembang memiliki kriteria praktis bagi anak.

Selanjutnya untuk mengetahui tingkat kepraktisan penggunaan LKPD ditinjau dari guru. Jumlah responden pada tahap ini tiga guru TK Pembina Negeri 2 Palembang bertempat di TK yang sama ketika peneliti melakukan penelitian. Responden mengajar pada kelompok B2 dua guru dan B3 satu guru. Pada tahap ini peneliti memberikan angket kepada responden dengan bentuk skala likert. Responden hanya memberikan cheklist sesuai dengan apa yang mereka rasakan. Pada tahap ini terdiri dari delapan pernyataan diantaranya 1) dengan adanya LKPD ini dapat membantu saya mengajar di kelas, 2) kejelasan indikator seingga dapat diukur, 3) dengan adanya tabel penilaian dapat memudahkan saya dalam menggunakan LKPD tersebut, 4) dengan adanya tabel penilaian dapat memudahkan saya dalam memberikan nilai hasil kerja anak, 5) setelah saya menggunakan LKPD ini saya tidak kerepotan lagi dalam menyediakan print out untuk anak, 6) setelah saya mengunakan LKPD ini saya semakin tahu materi tentang kota Palembang, 7) setelah saya menggunakan LKPD ini saya semakin percaya diri dalam memberikan materi, 8) materi yang terdapat dalam LKPD ini singkat, padat, jelas dan menarik. Berdasarkan delapan indikator di atas didapatkan hasil persentase guru dengan inisial YM sebesar 96\% dengan kategori sangat praktis, kemudian guru dengan inisial SZ didapatkan hasil persentase sebesar $100 \%$ kategori sangat praktis dan yang terakhir guru berinisial NR mendapatkan hasil persentase sebesar 96\% kategori sangat praktis sehingga hasil dari nilai angket kepraktisan terhadap LKPD didapatkan nilai rata-rata 97\% kategori sangat praktis. Sehingga dapat dikatakan bahwa LKPD Tema Tanah Airku Sub Tema Kota Palembang telah memenuhi tingkat kepraktisan.

Kepraktisan menurut Aryaningrum yang dikutip oleh (Asham, 2015, p. 8) ialah bersifat praktis dan mudah dalam pengadministrasiannya, seperti mudah dilaksanakan, dikoreksi atau diperiksa dan diberikan penilaian atau pensekoran yang dilengkapi dengan petunjuk yang jelas. Senada dengan pendapat di atas menurut Akker yang dikutip oleh (Sari, 2014) kepraktisan dapat terpenuhi jika para pakar dan praktisi menyatakan bahwa apa yang dikembangkan dapat diterapkan dan kenyataan menunjukkan bahwa apa yang dikembangkan dapat diterapkan dan 
digunakan dengan mudah. Produk yang dikembangkan dapat dikatakan praktis apabila produk yang dikembangkan mengandung unsur-unsur kondisi produk yang mudah digunakan oleh pemakai dalam hal ini adalah siswa dan guru, dan menimbulkan rasa menyenangkan, menarik dan berguna bagi siswa (Alfiriani \& Hutabri, 2017, p. 21). Jadi dapat dikatakan bahwa kepraktisan ialah apabila produk yang dikembangkan dapat diaplikasikan dan telah dinyatakan oleh para ahli, mudah pengadministrasiannya seperti mudah dilaksanakan, dikoreksi atau diperiksa, mudah dalam penskoran dan dilengkapi dengan petunjuk yang jelas dan mengacu pada kondisi produk sehingga dapat menimbulkan daya tarik, bermakna berguna dan menyenangkan ketika digunakan oleh guru dan siswa.

\section{SIMPULAN DAN SARAN}

Melalui penelitian pengembangan LKPD tema Tanah Airku subtema Kota Palembang yang telah dilakukan dapat disimpulkan berdasarkan hasil dari evaluasi materi dan desain dari LKPD yang dikembangkan dinyatakan sangat valid, sehingga LKPD ini layak digunakan sebagai bahan ajar untuk pembelajaran tema Tanah Airku dan subtema Kota Palembang hal ini didukung oleh hasil dari rata-rata validasi ahli atau expert review yang diperoleh senilai 3.77 sehingga termasuk dalam kategori sangat valid.

Kepraktisan LKPD dapat dilihat dari observasi anak dan angket yang diberikan kepada tiga guru. Hasil dari tahap one-to-one yang dilakukan oleh tiga peserta didik mendapatkan kategori sangat praktis dengan persentase sebesar 92\%. Kemudian pada tahap small group evaluation kategori sangat praktis yang diuji cobakan kepada sembilan peserta didik yang terdapat di kelompok B3 didapatkan hasil persentase kepraktisan senilai 92\% Kemudian tahap terakhir untuk melihat tingkat kepraktisan LKPD ialah angket guru, hasil dari nilai angket kepraktisan terhadap LKPD yang telah diperoleh nilai rata-rata 97\% kategori sangat praktis. Jadi dapat disimpulkan bahwa LKPD tema tanah airku sub tema kota Palembang telah memenuhi syarat valid dan praktis dan layak untuk digunakan pada pembelajaran tema tanah airku sub tema kota Palembang di TK Kelompok B.

Saran pada penelitian selanjutnya agar dapat dilakukan sampai tahap efek potensial guna melihat dampak dari produk yang akan dikembangkan terhadap peserta didik. Mengingat bahwa penelitian ini hanya melihat ke praktisan serta ke validan produk yang dikembangkan. Selain itu agar penelitian selanjutnya diharapkan dapat menambahkan satu variabel penelitian lagi untuk meningkatkan kemampuan tertentu pada anak usia dini..

\section{DAFTAR RUJUKAN}

Alfiriani, A., \& Hutabri, E. (2017). Kepraktisan dan Keefektifan Modul Pembelajaran Bilingual Berbasis Komputer. Kependidikan, 1(1).

Amirono, \& Daryanto. (2016). Evaluasi dan Penilaian Pembelajaran Kurikulum 2013. Yogyakarta: Gava Media.

Asham, B. (2015). Pengaruh Pemberian Tes Tertulis Setiap Akhir Pertemuan Terhadap Hasil Belajar Siswa Pada Mata Pelajaran Geografi di Kelas XI IPS SMA Negeri 20 Palembang Tahun Pelajaran 2014/2015. PGRI Palembang.

Centaury, B. (2015). Pengembangan Perangkat Pembelajaran Fisika Berbasis Inkuiri Pada Materi Alat Optik Dan Indikator Dampak Terhadap Kompetensi Siswa Kelas X SMA. Riset Fisika Edukasi Dan Sains, 1(2). 
Fatmawati, A. (2016). Pengembangan Perangkat Pembelajaran Konsep Pencemaran Lingkungan Menggunakan Model Pembelajaran Berdasarkan Masalah Untuk SMA Kelas X. Pendidikan Sains Dan Matematika, 4(2).

Haviz, M. (2013). Research and Development; Penelitian di Bidang Kependidikan yang Inovatif, Produktif dan Bermakna. Ta'dib, 16(1).

Permendikbud. Peraturan Menteri Pendidikan dan Kebudayaan Republik Indonesia tentang Kurikulum 2013 Pendidikan Anak Usia Dini. , (2014).

Permendikbud. Peraturan Menteri Pendidikan dan Kebudayaan Republik Indonesia tentang Standar Nasional Pendidikan Anak Usia Dini. , (2014).

Prawiradilaga, \& Salma, D. (2016). Prinsip Desain Pembelajaran. Jakara: Kencana.

Rahmawati, Y. (2012). Pengenalan Budaya Melalui Bercerita untuk Anak Usia Dini. Jurnal Pendidikan Anak, 1(1). https://doi.org/10.21831/JPA.V1I1.2908

Sari, P. M. (2014). Pengembangan Lembar Kerja Siswa Berbasis Konstruktivistik Pada Mata Pelajaran Ilmu Pengetahuan Sosial Di Sekolah Menengah Pertama. Universitas Sriwijaya.

Setyosari, P. (2016). Metode Penelitian Pendidikan \& Pengembangan. Jakarta: Kencana.

Sugiyono. (2013). Metode Penelitian Pendidikan, (Pendekatan Kuantitatif, Kualitatif, dan $R \& D)$. Bandung: Alfabeta.

Tessmer, M. (1993). Planing and Conducting Formative Evaluations. London: Kogan Page.

\section{AUTHOR}

Gustiana Yuantini. Akrabnya dipanggil Dina, anak ke-3 dari 4 bersaudara dan anak perempuan satu-satunya dari pasangan Drs. Sofuan dan Yuliha. Lahir di Palembang 07 Agustus 1996. Peneliti menjadi alumni tahun 2018 pada program studi PG. PAUD S1 di Universitas Sriwijaya Palembang. Peneliti sedang melanjutkan program magister di UIN Sunan Kalijaga program studi Pendidikan Islam Anak Usia Dini. Penulis dapat dihubungi melalui e-mail: yuantinigustiana@gmail.com. 